Acta Horticulturae et Regiotecturae 1

Nitra, Slovaca Universitas Agriculturae Nitriae, 2017, pp. 11-14

\title{
VARIETAL DISTRIBUTIONS OF STILBENES IN GRAPE CANE OF VITIS VINIFERA L.
}

\author{
Ivo SOURAL ${ }^{*}$, Josef BALÍK', Naděžda VRCHOTOVÁ2, Jan TŘíSKA² \\ ${ }^{1}$ Mendel University in Brno, Czech Republic \\ ${ }^{2}$ Global Change Research Institute, Academy of Sciences of the Czech Republic, Brno, Czech Republic
}

\begin{abstract}
Grape cane is a waste product from viticulture, which can be used as a source of stilbenes, such as resveratrol and viniferins with high antioxidant values. These stilbenes have also important healthy effects for humans. Resveratrol and viniferins are known as phytoalexins since 1977. Biomass of grape canes in annual pruning is a very valuable source of stilbenes, e.g. trans-resveratrol, and trans- $\varepsilon$-viniferin in dry grape canes. The main goal of this article was to compare the distribution of resveratrol and viniferins in the grape cane varieties of Laurot, Hibernal, Malverina and Chardonnay. The highest content of trans-resveratrol was found in Hibernal $\left(6,111 \mathrm{mg} \mathrm{kg}^{-1}\right)$; for trans- $\varepsilon$-viniferin and $\mathrm{r} 2$-vinifein, the highest levels were found in Malverina $\left(2,211 \mathrm{and} 654 \mathrm{mg} \mathrm{kg}^{-1}\right)$. These compounds can be obtained from this waste product (grape cane), by easy extraction process in winemaking or food-processing industry.
\end{abstract}

Keywords: Vitis vinifera L., varieties, grape canes, stilbenes, distribution

In wine production and viticulture technology there are a few waste plant materials: grape canes, grape marc, young lateral shoots and leaves (Balík et al., 2008). It is known from references that waste plant materials form a good source of stilbene-based substances in many more applications, such as pharmaceutical, cosmetic and food industries (Rayne et al., 2008; Xue et al., 2014).

Resveratrol, as a major stilbene derivative, has been studied in detail over the most recent decades (Langcake et al., 1976, 1977; Sotheeswaran et al., 1993). According to references, the substance is responsible for the so-called "French paradox" connected with wine consumption (Renaud et al., 1992; Catalgol et al., 2012). Next to resveratrol, there are other biologically active compounds, such as viniferins (Aaviksaar et al., 2003; Richard et al., 2011), piceid (Pawlus et al., 2013), pinosylvin (Park et al., 2012) and pterostilbene (McCormack et al., 2013).

According to references, alcohols are some of the best solvents for stilbene extraction out of the protic group of solvents (Rayne et al., 2008). We studied distribution of three types of stilbenes in different varieties of Vitis vinifera L. Extraction at $50{ }^{\circ} \mathrm{C}$ for more than two hours has a very high yield as observed in the previous study (Soural et al., 2015). Using higher temperature to increase the efficiency of extraction can destroy stilbenes. This work is focused on studying and comparing Laurot, Malverina, Hibernal and Chardonnay varieties and their extracting stilbene distribution from grape canes by ethanol.

\section{Material and methods}

\section{Varieties and locations}

Samples of grape canes of four Vitis vinifera L. cultivars, i.e. Laurot, Hibernal, Malverina and Chardonnay were studied. Description of varieties and growing sites: 1) Laurot is a blue inter-specific grape variety, a cross of ('Merlot' $\times$ 'Seibel 13 $\left.666^{\prime}\right) \times($ 'Blaufränkisch' $\times$ 'St. Laurent'); grown in the Wine Region Moravia, the Znojemská Wine Sub-region, Znojmo District, Znojmo-Oblekovice wine commune; 2) Hibernal is a white inter-specific grape variety, a cross of "Seibel $7053^{\prime} \times$ 'Riesling', grown in the Wine Region Moravia, the Velkopavlovická Wine Sub-region, Břeclav District, Rakvice wine commune; 3) Malverina is a white inter-specific grape variety, a cross of 'Merlan' $\times$ 'Rakish', grown in the same location as Hibernal; 4) Chardonnay is a white original variety, grown in the Wine Region Moravia, the Slovacká Wine Sub-region, Břeclav District, Kostice wine commune. All grape canes as one year old wood were pruned in same month - March 2013. Type of middle vine training RhineHesse was used in all varieties. Localities with geological and weather conditions (sum of effective temperatures above $10^{\circ} \mathrm{C}$ ) in year of pruning are in table 1.

\section{Extraction}

After pruning, grape canes of all varieties were cut to the approximate length of $10 \mathrm{~cm}$, then frozen and dried within a lyophilisation process and powdered using a knife grinder to achieve a size of around $1 \mathrm{~mm}$. $250 \mathrm{mg}$ of powdered grape canes and $3 \mathrm{ml}$ of methanol were immediately used

Contact address: Ing. Ivo Soural, Ph.D., Mendel University in Brno, Faculty of Horticulture, Department of Post-Harvest Technology of Horticultural Products, Valtická 337, Lednice 69144, Czech Republic, email: ivo.soural@mendelu.cz 
Table 1 Locality and their soil-geological settings and weather conditions

\begin{tabular}{|l||c|c|c|c|}
\hline Wine commune & GPS & Soil and geological settings & Sum of effective temperatures ('C) & Rainfall totals (mm) \\
\hline \hline $\begin{array}{l}\text { Znojmo - } \\
\text { Oblekovice }\end{array}$ & $\begin{array}{c}48^{\circ} 49^{\prime} 26.4^{\prime \prime} \mathrm{N} \\
16^{\circ} 05^{\prime} 30.8^{\prime \prime} \mathrm{E}\end{array}$ & $\begin{array}{c}\text { gravel-sand, sandy-loamy } \\
\text { chernozems }\end{array}$ & 1347 & 523 \\
\hline Rakvice & $\begin{array}{c}48^{\circ} 51^{\prime} 46.5^{\prime \prime} \mathrm{N} \\
16^{\circ} 48^{\prime} 00.3^{\prime \prime} \mathrm{E}\end{array}$ & $\begin{array}{c}\text { loess and clay, loamy } \\
\text { chernozems }\end{array}$ & 1340 & 431 \\
\hline Kostice & $\begin{array}{c}48^{\circ} 44^{\prime} 28.8^{\prime \prime} \mathrm{N} \\
16^{\circ} 58^{\prime} 28.5^{\prime \prime} \mathrm{E}\end{array}$ & $\begin{array}{c}\text { sand and clay, loamy-sandy } \\
\text { chernozems }\end{array}$ & 1459 & 696 \\
\hline
\end{tabular}

Table 2 Duncan's test for stilbenes in $\mathrm{mg} \mathrm{kg}^{-1} \mathrm{~d}$.w. of grape cane (One-way ANOVA)

\begin{tabular}{|c|c|c|c|c|c|}
\hline Varieties & Stilbenes & Laurot & Malverina & Hibernal & Chardonnay \\
\hline Laurot & $\begin{array}{l}\text { trans-resveratrol } \\
\text { trans- } \varepsilon \text {-viniferin } \\
\text { r2-viniferin }\end{array}$ & & $\begin{array}{l}0.0013 \\
0.0120 \\
0.0001\end{array}$ & $\begin{array}{l}0.0001 \\
0.2817 \\
0.0279\end{array}$ & $\begin{array}{l}0.4160 \\
0.3405 \\
0.0326\end{array}$ \\
\hline Malverina & $\begin{array}{l}\text { trans-resveratrol } \\
\text { trans- } \varepsilon \text {-viniferin } \\
\text { r2-viniferin }\end{array}$ & $\begin{array}{l}* * \\
* \\
* *\end{array}$ & & $\begin{array}{l}0.0003 \\
0.0553 \\
0.0002\end{array}$ & $\begin{array}{l}0.0006 \\
0.0479 \\
0.0001\end{array}$ \\
\hline Hibernal & $\begin{array}{c}\text { trans-resveratrol } \\
\text { trans- } \varepsilon \text {-viniferin } \\
\text { r2-viniferin }\end{array}$ & $\begin{array}{c}* * \\
\text { n.s. } \\
*\end{array}$ & $\begin{array}{c}\text { n* } \\
\text { n.s. } \\
* *\end{array}$ & & $\begin{array}{l}0.0001 \\
0.8544 \\
0.0010\end{array}$ \\
\hline Chardonnay & $\begin{array}{c}\text { trans-resveratrol } \\
\text { trans- } \varepsilon \text {-viniferin } \\
\text { r2-viniferin }\end{array}$ & $\begin{array}{l}\text { n.s. } \\
\text { n.s. } \\
*\end{array}$ & $\begin{array}{l}* * \\
* \\
* *\end{array}$ & $\begin{array}{c}\text { n* } \\
\text { n.s. } \\
* *\end{array}$ & \\
\hline Average & $\begin{array}{c}\text { trans-resveratrol } \\
\text { trans- } \varepsilon \text {-viniferin } \\
\text { r2-viniferin }\end{array}$ & $\begin{array}{c}1,604.5 \\
1,738.3 \\
159.9\end{array}$ & $\begin{array}{c}3,507.9 \\
2,210.7 \\
654.4\end{array}$ & $\begin{array}{c}6,111.0 \\
1,903.2 \\
231.9\end{array}$ & $\begin{array}{c}1,275.6 \\
1,877.2 \\
90.7\end{array}$ \\
\hline
\end{tabular}

${ }^{* *} p<0.01,{ }^{*} p<0.05$, n.s. $=$ not significant. Values are means calculated from three measurements

for extraction at $50{ }^{\circ} \mathrm{C}$ during 2 hours and $45 \mathrm{~min}$. After extraction, the mixtures were centrifuged for $10 \mathrm{~min}$ at 3,500 rpm and at laboratory temperature. The supernatants were transferred into calibrated tubes; $1 \mathrm{ml}$ of pure methanol was added to the solid residues, mixed and this new mixture was centrifuged once again. Subsequently, this rinse procedure was repeated a single time. All the supernatants were combined and the final volume of each supernatant mixture was adjusted to make $5 \mathrm{ml}$.

A similar process of extraction was done in the previous study with the Cabernet Moravia variety, when extraction yields were comparable with additional extraction steps (Soural et al., 2015).

\section{Quantification of stilbenes}

All the extract samples were analysed using the HP 1050 (Ti-series) HPLC instrument (Hewlett Packard, Palo Alto, CA, USA) on a column Luna C18(2) (Phenomenex, Torrance, CA, USA) with parameters: $3 \mu \mathrm{m}, 150 \times 2 \mathrm{~mm}$, the temperature of $25^{\circ} \mathrm{C}$, the flow rate of $0.250 \mathrm{ml} \mathrm{min}-1$. Mobile phase $A$ was $5 \%$ acetonitrile $+0.1 \%$ o-phosphoric acid (in vol.\%) in water; mobile phase B was $80 \%$ acetonitrile $+0.1 \%$ o-phosphoric acid (in vol. \%) in water. The gradient was increased from $20 \%$ mobile phase B to $80 \%$ of B during $20 \mathrm{~min}$ and from $80 \%$ of $B$ to $100 \%$ of $B$ during $5 \mathrm{~min}$. Injection volume was $5 \mu \mathrm{l}$. Two detectors were used for analysing: a diode array detector G1315B (DAD, Agilent, Prague, the Czech Republic) with the detection of wavelengths at 220 and $315 \mathrm{~nm}$ and a scanning range of 190-600 nm, and a fluorescence detector G1321A (FLD, Agilent, Prague, the Czech Republic) with excitation wavelength of $315 \mathrm{~nm}$, emission wavelength of $395 \mathrm{~nm}$, and scanning of emission in the $300-600 \mathrm{~nm}$ range. Finally, the method of quantification was validated in terms of linearity, limits of detection, and repeatability (Tríska et al., 2012, 2013). Identifications of stilbenes (trans-resveratrol, trans$\varepsilon$-viniferin and $\mathrm{r}$ 2-viniferin) were done previously by HRMS (High Resolution Mass Spectrometr) and H-NMR (Nuclear Magnetic Resonance) as presented by Soural et al. (2015).

\section{Statistical analysis}

All extracts of grape canes with stilbenes were measured three times. Mean values, standard deviations and significant vs. non-significant differences ( $p<0.01$ or $p<0.05$ ) were analysed by ANOVA, applying the Tukey multiple range test for making comparisons with Statistica Cz 12 and MS Excel 2010 software.

\section{Results and discussion}

Contents of stilbenes in extracts of grape cane for all varieties Vitis vinifera $\mathrm{L}$. were calculated to achieve amounts of $\mathrm{mg} \mathrm{kg}^{-1}$ of dried grape cane.

The contents of trans-resveratrol in different varieties showed statistical differences by Duncan's test of one-way ANOVA in all four measured varieties, except Chardonnay vs. Laurot. A minimum of trans-resveratrol $\left(1,276 \mathrm{mg} \mathrm{kg}^{-1}\right.$ d.w.) was present in the Chardonnay and the Laurot variety with a similar content $\left(1,604 \mathrm{mg} \mathrm{kg}^{-1}\right)$. A maximum of transresveratrol $\left(6,111 \mathrm{mg} \mathrm{kg}^{-1}\right)$ was found in Hibernal. Malverina's value $\left(3,508 \mathrm{mg} \mathrm{kg}^{-1}\right)$ was near to the average of all four varieties $\left(3,125 \mathrm{mg} \mathrm{kg}^{-1}\right)$. Between Hibernal and Chardonnay, 


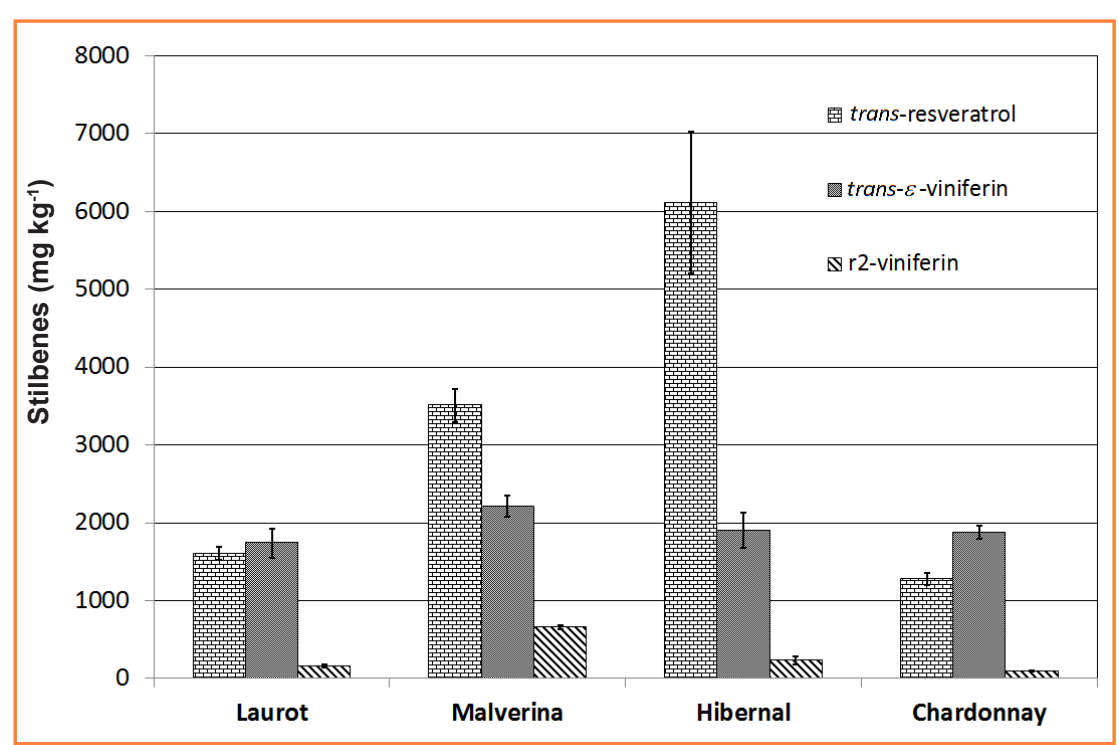

Figure 1 Stilbenes distribution in the grape canes of four varieties Vitis vinifera $\mathrm{L}$.

as maximum vs. minimum values of trans-resveratrol, there was almost five times disparity (exactly more than 379\%).

In case of contents of trans$\varepsilon$-viniferin in these varieties there were no statistical differences except between Malverina and two varieties of Laurot and Chardonnay. Contents of trans- $\varepsilon$-viniferin were almost same: Laurot (1,738 $\mathrm{mg} \mathrm{kg}^{-1}$ d.w.), Hibernal $\left(1,903 \mathrm{mg} \mathrm{kg}^{-1}\right)$ and Chardonnay $\left(1,877 \mathrm{mg} \mathrm{kg}^{-1}\right)$ with values around $1,800 \mathrm{mg} \mathrm{kg}^{-1}$ d.w. Only varieties Malverina had significant higher content $\left(2,211 \mathrm{mg} \mathrm{kg}^{-1}\right)$, but equalled only around $20 \%$, approximately.

Among the last-measured stilbenes there was r2-viniferin, with very different contents in all varieties. The maximum was found in the grape cane of Malverina (654 $\mathrm{mg} \mathrm{kg}^{-1}$ d.w.), while minimum in Chardonnay (91 $\mathrm{mg} \mathrm{kg}^{-1}$ ) this is more than seven times disparity. The Laurot (160 mg kg-1) and Hibernal $\left(232 \mathrm{mg} \mathrm{kg}^{-1}\right.$ ) varieties had approximately four times or three times lesser content of r2-viniferin than Malverina. Between Malverina and Chardonnay (as maximum vs. minimum) of $\mathrm{r}$-viniferin, there was approximately seven times disparity (exactly more than 621\%).

Standard deviation values along with contents are shown in Figrue 1.

Malverina showed higher contents of oligomers of resveratrol (trans- $\varepsilon$ viniferin as dimer and $r 2$-viniferin as tetramer); these results are of statistical significance. The lowest amounts of sums of stilbenes $3,244 \pm 170 \mathrm{mg} \mathrm{kg}^{-1}$ d.w. were found in Chardonnay in contrast with the highest amounts of stilbenes $8,246 \pm 1,190 \mathrm{mg} \mathrm{kg}^{-1}$ in cv. Hibernal. Comparing Hibernal with Cabernet Moravia with the value of $8,500 \mathrm{mg} \mathrm{kg}^{-1}$ (Soural et. al., 2015) showed similar contents of stilbenes in the two different varieties. Pinot noir with the content of $6,900 \mathrm{mg} \mathrm{kg}^{-1}$ (Vergara et al., 2012) showed similar results as Malverina with the value of $6,373 \pm 375 \mathrm{mg} \mathrm{kg}^{-1}$.

Contents of stilbenes are not depending only on the variety but mainly on the storing condition or the process of preparation before extracting, drying, etc. For example, content of $\varepsilon$-viniferin in Chardonnay was found to be $2,089 \pm 334 \mathrm{mg} \mathrm{kg}^{-1}$ d.w. as published by Lambert et al. (2013) which is similar to our result of 1,887 $\pm 89 \mathrm{mg} \mathrm{kg}^{-1}$ as reported herein, but contents of trans-resveratrol were totally different: $190 \pm 87 \mathrm{mg} \mathrm{kg}{ }^{-1}$ (Lambert et al., 2013) and our value was only $1,276 \pm 75 \mathrm{mg} \mathrm{kg}^{-1}$. This big difference can be caused by various drying processes.

In the study published by Lambert et al. (2013) drying occurred at the temperature of $40{ }^{\circ} \mathrm{C}$ during 15 days period but in our case there was immediately freezing and lyophilisation; in our previous study (Soural et. al., 2015) drying took place at the room temperature $\left(22^{\circ} \mathrm{C}\right.$ approximately) for 2.5 months in darkness. In the study of Houillé et al. (2015) we can generally see increasing contents of stilbene over time and higher temperature of storing.

Next to storing conditions, Wine Sub-regions can play role, although all samples are from one Wine Region Moravia. Some differences in: weathers, soils, geological settings and types of arotechnics, can change contents of stilbenes. These effects are in more detail studied in our further publication (in a review process) but with grape cane pruned in years 2014-2016. Not only varieties differences must be studied in this phenomenon.

\section{Conclusion}

The present study compared four varieties of Vitis vinifera L.: Laurot, Hibernal, Malverina and Chardonnay in terms of sourcing viniferins and transresveratrol from grape canes as waste plant materials from wine production and viticulture technology. This obtaining of stilbenes can improve economic side of winemakers or can be applied in food-processing industry. Distribution of these stilbenes is highly variable; there was more than 7 times disparity between Malverina and Chardonnay in case of r2-viniferin. Similar disparity (5 times) occurred between Hibernal and Chardonnay in the case of contents of trans-resveratrol; very similar results were obtained, however, in the case of trans- $\varepsilon$-viniferin, with the disparity being only 1.27 times between Malverina and Laurot. A maximum of these tree stilbenes was found in the Hibernal variety, the value being 8,246 $\pm 1,190 \mathrm{mg} \mathrm{kg}^{-1} \mathrm{~d}$.w. of grape cane.

Comparing the results of this study against bibliography showed differences in distribution of stilbenes. Different contents of stilbenes in the same variety can be produced by differences in storage-drying process, weather and soil-geological settings. These phenomena should be explored in more detail.

\section{Acknowledgements}

This work was supported by the Ministry of Education, Youth and Sports of the Czech Republic by the COST Research Project, number LD14038 and by the National Sustainability Program I (NPU I), grant number LO1415. 


\section{References}

AAVIKSAAR, A. - HAGA, M. - PUSSA, T. - ROASTO, M. - TSOUPRAS, G. 2003. Purification of resveratrol from vine stems. In Proceedings of the Estonian Academy of Sciences: Chemistry, vol. 52, 2003, no. 4, pp. 155-164.

BALÍK, J. - KYSELÁKOVÁ, M. - VRCHOTOVÁ, N. - TŘíSKA, J. KUMŠTA, M. - VEVERKA, J. - HÍC, P. - TOTUŠEK, J. - LEFNEROVÁ, D. 2008. Relations between polyphenols content and antioxidant activity in vine grapes and leaves. In Czech Journal of Food Sciences, vol. 26, 2008, pp. 25-32.

CATALGOL, B. - BATIREL, S. - TAGA, Y. - OZER, N. K. 2012. Resveratrol: French paradox revisited. In Front Pharmacol, vol. 3, 2012, no. 141, p. 141.

HOUILLÉ, B. - BESSEAU, S. - COURDAVAULT, V. - OUDIN, A. GLÉVAREC, G. - DELANOUE, G. - GUÉRIN, L. - SIMKIN, A. J. PAPON, N. - CLASTRE, M. - GIGLIOLI-GUIVARC'H, N. - LANOUE, A. 2015. Biosynthetic Origin of E-Resveratrol Accumulation in Grape Canes during Postharvest Storage. In Journal of Agricultural and Food Chemistry, vol. 63, 2015, no. 5, pp. 1631-1638.

LAMBERT, C. - RICHARD, T. - RENOUF, E. - BISSON, J. - WAFFOTÉGUO, P. - BORDENAVE, L. - OLLAT, N. - MÉRILLON, J. M. CLUZET, S. 2013. Comparative analyses of stilbenoids in canes of major Vitis vinifera L. cultivars. In Journal of Agricultural and Food Chemistry, vol. 61, 2013, no. 47, pp. 11392-11399

LANGCAKE, P. - PRYCE, R. J. 1976. The production of resveratrol by Vitis vinifera and other members of the Vitaceae as a response to infection or injury. In Physiological Plant Pathology, vol. 9, 1976, no. 1, pp. 77-86.

LANGCAKE, P. - PRYCE, R. J. 1977. The production of resveratrol and the viniferins by grapevines in response to ultraviolet irradiation. In Phytochemistry, vol. 16, 1977, no. 8, pp. 1193-1196.

McCORMACK, D. - McFADDEN, D. 2013. A review of pterostilbene antioxidant activity and disease modification. In Oxidative Medicine and Cellular Longevity, 2013, pp. 1-15.

PARK, E. J. - PARK, H. J. - CHUNG, H. J. - SHIN, Y. - MIN, H. Y. - HONG, J. Y. - KANG, Y. J. - AHN, Y. H. - PYEE, J. H. - LEE, S K. 2012. Antimetastatic activity of pinosylvin, a natural stilbenoid, is associated with the suppression of matrix metalloproteinases. In Journal of Nutritional Biochemistry, vol. 23, 2012, no. 8, pp. 946-952.

PAWLUS, A. D. - SAHLI, R. - BISSON, J. - RIVIÈRE, C. - DELAUNAY, J. C. - RICHARD, T. - GOMĖS, E. - BORDENAVE, L. - WAFFO-TÉGUO, P. - MÉRILLON, J. M. 2013. Stilbenoid profiles of canes from Vitis and
Muscadinia species. In Journal of Agricultural and Food Chemistry, vol. 61, 2013, no. 3, pp. 501-511.

RAYNE, S. - KARACABEY, E. - MAZZA, G. 2008. Grape cane waste as source of trans-resveratrol and trans-viniferin: highvalue phytochemicals with medicinaland anti-phytopathogenic applications. In Industrial Crops and Products, vol. 27, 2008, no. 3, pp. 335-340.

RENAUD, S. - de LORGERIL, M. 1992. Wine, alcohol, platelets, and the French paradox for coronary heart disease. In Lancet, vol. 339, 1992, pp. 1523-1526.

RICHARD, T. - POUPARD, P. - NASSRA, M. - PAPASTAMOULIS, Y. IGLESIAS, M. L. - KRISA, S. - WAFFO-TEGUO, P. - MERILLON, J. M. - MONTI, J. P. 2011. Protective effect of $\varepsilon$-viniferin on $\beta$-amyloid peptide aghgregation investigated by electrospray ionization mass spectrometry. In Bioorganic @ Medicinal Chemistry, vol. 19, 2011, no. 10, pp. 3152-3155.

SOTHEESWARAN, S. - PASUPATHY, V. 1993. Distribution of resveratrol oligomers in plants. In Phytochemistry, vol. 32, 1993, no. 5, pp. 1083-1092.

SOURAL, I. - VRCHOTOVA, N. - TRISKA, J. - BALIK, J. - HORNIK S. - CURINOVA, P. - SYKORA, J. 2015. Various Extraction Methods for Obtaining Stilbenes from Grape Cane of Vitis vinifera L. In Molecules, vol. 20, 2015, no. 4, pp. 6093-6112.

TŘíSKA, J. - VRCHOTOVÁ, N. - OLEJNÍČKOVÁ, J. - JÍLEK, R. SOTOLÁŘ, R. 2012. Separation and identification of highly fluorescent compounds derived from trans-resveratrol in the leaves of Vitis vinifera infected by Plasmopara viticola. In Molecules, vol. 17, 2012, no. 3, pp. 2773-2783.

TŘíSKA, J. - VRCHOTOVÁ, N. - SÝKORA, J. - MOOS, M. 2013. Separation and identification of 1,2,4-trihydroxynaphthalene-1O-glucoside in Impatiens glandulifera Royle. In Molecules, vol. 18, 2013, no. 7, pp. 8429-8439.

VERGARA, C. - VON BAER, D. - MARDONES, C. - WILKENS, A. - WERNEKINCK, K. - DAMM, A. - MACKE, S. - GORENA, T. WINTERHALTER, P. 2012. Stilbene levels in grape cane of different cultivars in southern Chile: Determination by HPLC-DAD-MS/MS method. In Journal of Agricultural and Food Chemistry, vol. 60, 2012, no. 4, pp. 929-933.

XUE, Y. Q. - DI, J. M. - LUO, Y. - CHENG, K. J. - WEI, X. - SHI, Z. 2014. Resveratrol Oligomers for the Prevention and Treatment of Cancers. In Oxidative Medicine and Cellular Longevity, 2014, 9 p. 